\title{
OGFR wt Allele
}

National Cancer Institute

\section{Source}

National Cancer Institute. OGFR wt Allele. NCI Thesaurus. Code C113118.

Human OGFR wild-type allele is located in the vicinity of $20 \mathrm{q} 13.3$ and is approximately $9 \mathrm{~kb}$ in length. This allele, which encodes opioid growth factor receptor protein, plays a role in Met-enkephalin-dependent signaling. 